\title{
The Edinburgh intercalated honours BSc in pathology: evaluation of selection methods, undergraduate performance, and postgraduate career
}

\author{
ANDREW H WYLLIE, ALASTAIR R CURRIE
}

\begin{abstract}
In a study of 60 students who entered the intercalated honours BSc course in pathology at the University of Edinburgh over 10 years the conventional criteria of academic excellence and motivation were shown to be appropriate for the selection of honours students. When compared with classmates who did not take the intercalated year but who had shown similar high academic ability in the preclinical course the students who had taken the honours BSc did better in the remainder of the undergraduate curriculum. Of 42 honours students, $18(43 \%)$ entered academic careers, particularly in pathology and medicine, but there was no observed tendency for students without honours BSc to do so.

Although it is impossible to establish a causal relation between taking the honours course and subsequent academic distinction, the results suggest that the intercalated honours BSc in pathology serves a useful function in introducing able students into academic careers. The findings justify the financial support made available to such students during their intercalated year by the Medical Research Council and the Scottish Education Department.
\end{abstract}

\section{Introduction}

The intercalated honours BSc course is now an established feature in many medical schools in this country. Lasting for one year, or occasionally two, the course is offered by several preclinical and paraclinical departments and is aimed at introducing students to careers in medicine in which investigative work is an important component. Despite the length of the medical curriculum students continue to undertake intercalated years and appear to value them. Nevertheless, only one published study has attempted an objective evaluation of an intercalated honours course,' and we know of no study that has examined whether the methods used to select candidates for the intercalated degree are adequate.

The teaching of honours students is labour intensive out of all proportion to their numbers. When, as is often the case, there is a large experimental component in the course it is expensive: materials for a project lasting six months may cost over $£ 1000$. The

\footnotetext{
Department of Pathology, University of Edinburgh Medical School, Edinburgh EH8 9AG

ANDREW H WYLLIE, PHD, MRCPATH, reader

ALASTAIR R CURRIE, FRCPATH, FRSE, professor

Correspondence to: Dr Wyllie.
}

cost of maintaining a student at university for an extra year is also substantial. Although the Scottish Education Department has consistently awarded the "normal" grant to medical students during the intercalated honours year, few English local education authorities do so, though grants are sometimes made on a "discretionary" basis, and intercalated students from Northern Ireland never receive grants from the responsible library boards. Consequently, the Medical Research Council (MRC) started to provide grants to students living in England and Northern Ireland to help them to undertake the intercalated year. Recently, owing to financial stringency, the total number of such grants awarded by the MRC has been rationed: 10 were awarded to students at the University of Edinburgh in 1985.

Two vears ago the MRC asked the committee of vice chancellors and principals to provide evidence of the value of the intercalated course. This inquiry was stimulated by a formal question from the National Audit Office asking whether "the awards made by the Council under this scheme have become of such a general educational (rather than research) nature as to be no longer a proper charge on the Council's funds" (J L Gowans, letter sent from the MRC to deans of the faculty of medicine in the United Kingdom, 21 November 1983).

In this paper we evaluate the honours course in pathology at the University of Edinburgh over 10 years' intake (1973-82). The structure of this one year course is similar to intercalated courses in other departments at the university and other medical schools in the UK. During the first two terms an experimental project is undertaken, which is eventually presented as a thesis. Thesis topics range from basic cell biology to applied case related studies and are chosen by the students after discussion with the prospective supervisors. The more structured element of the course entails critical evaluation of scientific reports in selected areas-for example, inflammation, cellular immunology, and tumour biology. Clinical applications are emphasised in a weekly, one hour discussion on necropsy and biopsy specimens. During the 10 vears studied the criteria for selection and the methods of assessment of our honours students were consistent. Students undertaking the $\mathrm{BSc}$ in pathology make up roughly a quarter of the total number of students taking intercalated honours at the university; mcst of the other students take courses offered by the departments of bacteriology, biochemistry, pharmacology, and physiology.

\section{Subjects and methods}

Sixty students undertook the honours BSc in pathology at the University of Edinburgh from 1973 to 1982 , the class size being limited to a maximum of seven each year. All but five took the intercalated year after completing a course in general pathology and immediately before the first clinical year. We studied the performance of the pathology honours students in their final school examinations, their degree examination marks in 
pathology before and after the honours course, the class of honours degree they obtained, their marks in clinical subjects in the final MB, ChB examinations (medicine, surgery, obstetrics, paediatrics, and psychiatry), and, for the 42 students who had graduated by 1983 , their subsequent career choices.

Performance in the final school examinations was scored by allocating 3 to an A grade pass in the Scottish Higher Leaving Certificate or in the English A level, 2 to a $\mathrm{B}$, and 1 to a $\mathrm{C}$ and summing all the scores. Performance in clinical subjects other than pathology was treated similarly, but the scores allocated to passes at A, B, C, and D grades were $4,3,2$, and 1 , respectively. In the $M B$ course performance in pathology was gauged from the percentage obtained in the degree examinations in general pathology (phase I, preclinical) and in applied pathology (phase II, clinical).

Inclusion in the honours course required academic excellence and motivation. Academic excellence was judged from the marks in the preceding degree examination in pathology; only the top 10-15 students of the $150-180$ in the year were invited. Good grades were also required in the degree examinations in other subjects. All eligible and interested students were interviewed and motivation assessed from the students' readiness to undertake the intercalated year. At the end of the year the students were assessed by the results of two written papers and an oral examination with the external examiner, in which the presentation and defence of the thesis was also taken into account.

Honours students were compared with two other groups of students. Firstly, the peer group, which consisted of students who did not take any of the offered honours BSc courses but whose marks in the preceding degree examination in pathology were within the same range as the honours group. Broadly, this group shared the academic excellence but lacked the motivation of the honours group. The students in this group represented nearly all the available students who had marks in the appropriate range. Secondly, the subpeer group, which comprised students whose marks in the relevant selection examination fell $10 \%$ below those of the prospective honours students. Some of these students would have been keen to enter the honours course had they been invited but were excluded because of their poorer academic performance. As far as possible all three groups were balanced for sex within each interval of marks. Similar proportions in all three groups had been supported by the Scottish Education Department and English local education authorities.

Examination results were compared by the Wilcoxon test for independent samples. The students' postgraduate career choices were obtained by personal contact and by a search of the Medical Directory.

\section{Results}

To establish whether the methods of selecting students for the honours course were appropriate we examined the relation between performance in the honours year and the preceding selection examination in pathology. The class of honours degree awarded depended on the final assessment of the external examiner, and over the 10 years studied the three external examiners differed little in the proportion of first class or upper second class honours they awarded (table I); no lower second class honours degrees were awarded. Despite anecdotal exceptions the students who gained first class honours degrees tended to have had significantly higher marks at selection than those who gained upper second class honours degrees $(p<0.02)$. In subsequent degree examinations in the $\mathrm{MB}, \mathrm{ChB}$ course the students who

TABLE I-Students undertaking honours BSC in pathology in the University of Edinburgh

\begin{tabular}{|c|c|c|c|c|c|c|c|}
\hline \multirow{2}{*}{$\begin{array}{l}\text { Year of } \\
\text { entry to } \\
\text { honours } \\
\text { school }\end{array}$} & \multirow{2}{*}{$\begin{array}{l}\text { External } \\
\text { examiner }\end{array}$} & \multicolumn{2}{|c|}{ Entry from } & \multicolumn{2}{|c|}{ No of students } & \multicolumn{2}{|c|}{ Class of degree } \\
\hline & & Phase $I^{\star}$ & Phase II $†$ & $\mathbf{M}$ & $\mathrm{F}$ & 1 & $2: 1$ \\
\hline $\begin{array}{l}1973 \\
1974 \\
1975 \\
1976\end{array}$ & $\begin{array}{l}\text { Director of Institute } \\
\text { of Cancer Research, } \\
\text { London }\end{array}$ & $\begin{array}{l}5 \\
4 \\
6 \\
6\end{array}$ & 1 & $\begin{array}{l}4 \\
3 \\
4 \\
5\end{array}$ & $\begin{array}{l}2 \\
1 \\
3 \\
1\end{array}$ & $\begin{array}{l}3 \\
3 \\
4 \\
2\end{array}$ & $\begin{array}{l}3 \\
1 \\
3 \\
4\end{array}$ \\
\hline $\begin{array}{l}1977 \\
1978 \\
1979\end{array}$ & $\begin{array}{l}\text { Professor of pathology, } \\
\text { University of Bristol }\end{array}$ & $\begin{array}{l}6 \\
6 \\
6\end{array}$ & 1 & $\begin{array}{l}5 \\
2 \\
5\end{array}$ & $\begin{array}{l}2 \\
4 \\
1\end{array}$ & $\begin{array}{l}2 \\
3 \\
4\end{array}$ & $\begin{array}{l}5 \\
3 \\
2\end{array}$ \\
\hline $\begin{array}{l}1980 \\
1981 \\
1982\end{array}$ & $\begin{array}{l}\text { Director of MRC } \\
\text { Laboratory of Molecu- } \\
\text { lar Biology, Cambridge }\end{array}$ & $\begin{array}{l}6 \\
4 \\
6\end{array}$ & $\begin{array}{l}1 \\
1\end{array}$ & $\begin{array}{l}4 \\
3 \\
3\end{array}$ & $\begin{array}{l}2 \\
2 \\
4\end{array}$ & $\begin{array}{l}2 \\
0 \\
4\end{array}$ & $\begin{array}{l}4 \\
5 \\
3\end{array}$ \\
\hline Total & & 55 & 5 & 38 & 22 & 27 & 33 \\
\hline
\end{tabular}

* Students entering the intercalated year from phase I had completed a degree course in general pathology but had no direct clinical experience.

† Students entering the intercalated year from phase II had in addition one year's clinical experience and had completed a degree course in applied pathology.
TABLE II-Career choices of graduates up to 1983 from the honours and peer groups

\begin{tabular}{|c|c|c|c|c|c|}
\hline \multirow[b]{2}{*}{ Career choice } & \multicolumn{3}{|c|}{ Honours group } & \multicolumn{2}{|c|}{ Peer group } \\
\hline & $\underset{(\%)}{\text { Number }}$ & M:F & $\begin{array}{c}\text { First class } \\
\text { honours } \\
\text { degree }\end{array}$ & $\underset{(\%)}{\text { Number }}$ & M:F \\
\hline Pathology & $10(24)$ & 9:1 & 7 & 0 & \\
\hline Haematology & $2(5)$ & $0: 2$ & 1 & 0 & \\
\hline Medicine & $11(26)$ & $8: 3$ & 5 & $4(10)$ & $3: 1$ \\
\hline Surgery & $5(12)$ & $4: 1$ & 3 & $2(5)$ & $2: 0$ \\
\hline Obstetrics & $3(5)$ & $1: 2$ & 1 & $3(8)$ & $1: 2$ \\
\hline Paediatrics & $1(2)$ & $0: 1$ & 0 & $3(8)$ & $3: 0$ \\
\hline General practice & $7(17)$ & $4: 3$ & 2 & $16(41)$ & $12: 4$ \\
\hline Others in medicine & $3(7)$ & $1: 2$ & 2 & $2(5)$ & $1: 1$ \\
\hline Lost to follow up & 0 & & 0 & $5(13)$ & $4: 1$ \\
\hline Not in medicine & 0 & & 0 & $4(10)$ & $0: 4$ \\
\hline Total & 42 & $27: 15$ & 21 & 39 & $26: 13$ \\
\hline Pathology for $<2$ years ${ }^{\star}$ & 15 & $13: 2$ & 9 & 0 & \\
\hline Continuing research $\dagger$ & 18 & $15: 3$ & 13 & 0 & \\
\hline
\end{tabular}

*Includes graduates who were still working in pathology after two years.

tThe proportion of honours graduates employed in academic careers is highly significant $(\mathbf{p}<0.0001)$. The greater tendency for graduates gaining first class honours degrees, compared with those with second class honours degrees, to take up such careers is also significant $(p<0.05$; fourfold table test).

had gained first and second class honours degrees did not perform measurably differently, but a much higher proportion of first class honours graduates subsequently engaged in research careers (see table II) and took up research fellowships (see below). This suggests that the distinction between first and upper second class honours degrees reflects qualities other than merely the ability to do well in examinations. The positive associations between higher marks in the selection examination, better class of honours degree, and commitment to academic life thereafter suggest that the methods of selection are appropriate. In view of the data it is improbable that relaxation of the academic criteria would increase the efficiency with which high quality students are selected for the course.

The figure compares the previous and subsequent undergraduate performance of the honours pathology students with those of the peer and subpeer groups. At the time of leaving school, after allowing for the different styles of the English and Scottish examinations, the academic achievements of students in all three groups were indistinguishable. Within a year after the completion of the honours course the honours students' performance in pathology was substantially better than that of both the peer and subpeer groups. This difference was also apparent in clinical subjects and was sustained to the end of the undergraduate medical curriculum.

The students who undertook the pathology honours course from 1973 to 1981 have subsequently graduated. In these nine years the award for the most distinguished graduate in medicine (the Ettles scholar) was given on six occasions to a student with the pathology honours BSc. Ettles scholars are chosen on the basis of their entire undergraduate performance in the $M B$, $\mathrm{ChB}$ course; the weighting of pathology is small $(6 \%)$.

Table II gives the career choices of the group of students who completed the honours BSc in pathology and of the peer group. The data show that nearly one third of the pathology honours graduates worked for some time in our own or other university departments of pathology after registration. Several of these graduates spent a year in pathology before taking up their chosen career in surgery; thus the proportion ultimately selecting pathology as their specialty was nearer one quarter. Among the graduates who entered specialties other than pathology, however, many also tended towards academic careers. In total $18(43 \%)$ out of 42 honours pathology BSc graduates became employed in investigative laboratory work. This is reflected in the research fellowships held by the honours graduates. Of the 23 honours graduates who had been registered more than five years, eight had received research fellowships: from the MRC (three), Cancer Research Campaign (one), Wellcome Foundation (two), and other grant giving organisations (two). Interestingly, seven of these graduates had gained first class honours BSc degrees. By contrast, medical graduates from the peer group showed little tendency to become employed in continuing research work. In addition, more women from this group tended to "drop out" from active medical careers over the short period studied. A larger proportion of the subpeer group were lost to follow up, but for the graduates for whom we had data $(29(66 \%)$ out of 44$)$ the career choices were similar to those of the peer group.

\section{Discussion}

Previous studies have shown that students who perform well in the paraclinical part of the medical curriculum tend to be a 

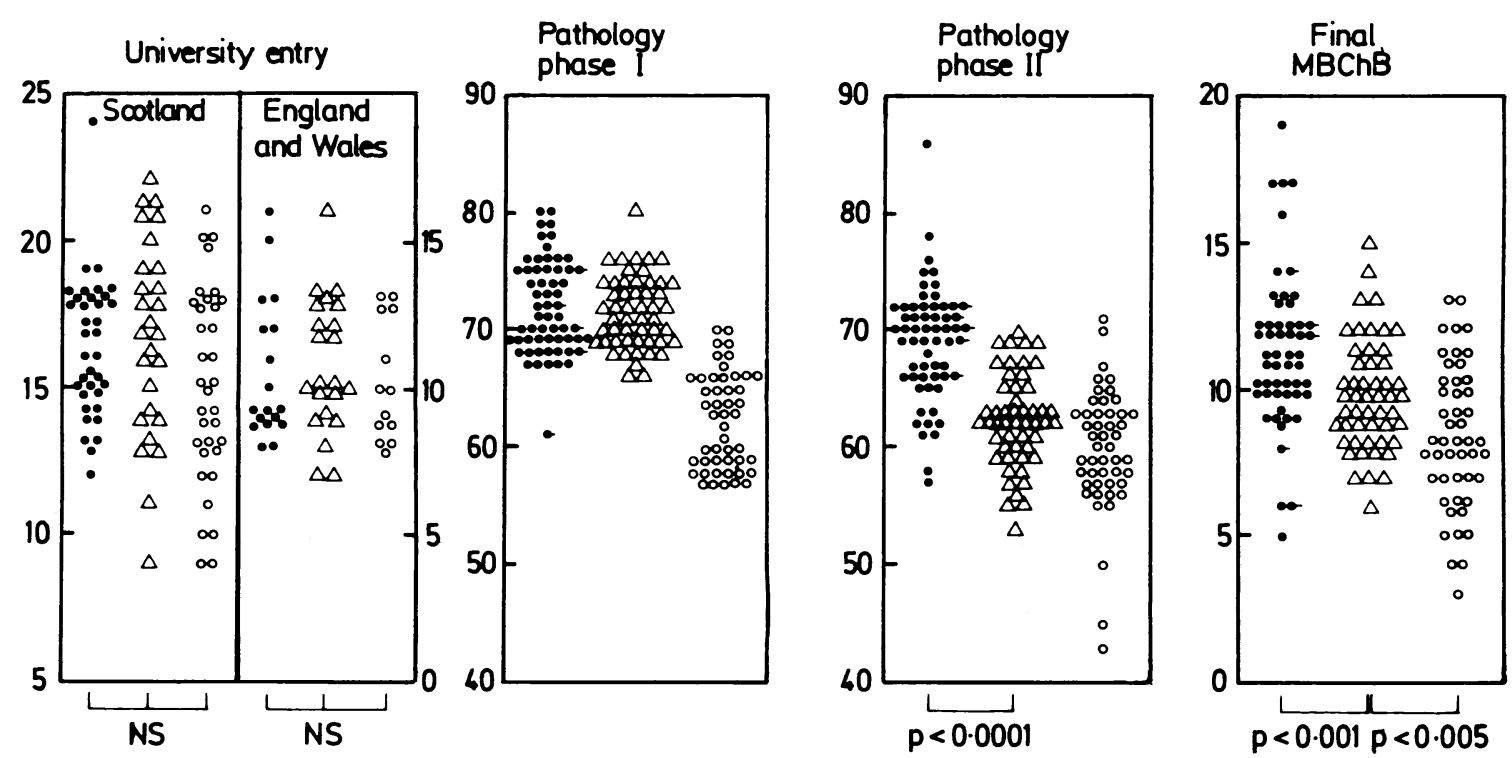

Scores and percentage marks of students in the honours $(\odot)$, peer $(\triangle)$, and subpeer $(\bigcirc)$ groups. Phase I and phase II refer to the degree examinations after the general and applied course in pathology, and students entering the honours course after phase II are distinguished by the symbol - - Students entering university with Scottish Higher Leaving Certificates are shown separately (and on different scales) from students with English GCE qualifications to account for the smaller number of subjects presenting with GCEs.

psychologically distinctive group of "imaginative, sensitive, and tolerant individuals." The students who undertake the intercalated course in pathology presumably combine these traits with the motivation for investigative work. It is uncertain whether the experience of taking the honours BSc is the cause or the effect of the students' continuing motivation and academic excellence. The honours students themselves often asserted that the intercalated year helped to equip them with analytical skills, and generally their undergraduate performance after the honours year was better than that of students previously assessed as their equals, both at entry to medical school and immediately before the intercalated year. Even if this merely reflects the same drive that led them to choose the intercalated year in the first place our data strongly support the claim that the honours course is being taken by a worthy group of students.

Although our assessment was restricted to academic activity, we were impressed that students selected on this basis proved to be unusually gifted in many ways that could not be measured by formal examinations. Our honours students had taken part in expeditions to remote parts of the world, featured as television communicators, won awards in athletics, and initiated dramatic, musical, and literary productions.

A survey of the career decisions of the most distinguished graduates in medicine each year at Edinburgh University for the century 1868-1969 showed that $20 \%$ of these graduates became professors, whereas the proportion who took up careers with less prominent academic and research activities was similar to that seen in our honours group. ${ }^{3}$ The pathology honours students in this survey are not yet old enough to lead academic departments but nearly half are dedicated to academic careers. This contrasts with the career choices of the peer and subpeer groups and also to well documented cohorts of unselected graduates at other British medical schools, in which less than $4 \%$ entered academic branches of medicine. ${ }^{5}$ In a follow up study at the University of Queensland, $20 \%$ of graduates who had the bachelor of medical science qualification were in full time academic or research positions compared with only $0.9 \%$ in the control group, which unlike ours was not selected for academic excellence at any stage in the undergraduate curriculum.

The data show that our honours course in pathology successfully attracted a group of gifted young people destined for investigative careers, many of them in academic pathology, at a time when recruitment to pathology departments was poor in the UK and overseas. There can be little question that the experience of the intercalated year allowed realistic evaluation of the students' potential as research workers, both by themselves and by their tutors. We also noted that the graduates' current chosen subjects of $\vec{\sigma}$ study usually stemmed from interests developed in the course of the research work in their intercalated year.

Although we attempted to select relevant control groups, there is inevitably some uncertainty about the cause and effect intrinsic to all studies of career preferences. Our study was also strictly limited to the single intercalated honours course, with which we were familiar. Nevertheless, we think that these findings show the ? remarkable efficiency of an intercalated honours BSc course in fostering the development of medical scientists and justify the financial investment made by the Scottish Education Department and the Medical Research Council.

We thank Mrs Margo Boyle for her help in gathering much of the data in this paper and Dr Robin J Prescott for statistical advice.

\section{References}

1 Eaton DG, Thong YH. The bachelor of medical science research degree as a start for clinicianscientists. Med Educ 1985;19:445-51.

2 Huxham GJ, Lipton A, Hamilton D. Achievement factors and personality in a cohort of medical students. Med Educ 1980;14:97-104.

3 Wilson HD. A hundred years of the Ettles Scholarship at the University of Edinburgh. Med Educ $1981 ; 15: 359-62$.

4 Egerton EA. Career preference enquiry amongst Queen's University medical undergraduates and graduates: a follow up. Med Educ 1983;17:105-11.

5 Parkhouse J. A follow-up of career preferences. Med Educ 1976;10:480-2.

(Accepted l April 1986)

What tests-suitable for use in general practice-are available to detect cocaine and marijuana in the urine?

So far as I am aware only one system is available for detecting cocaine and cannabinoids in urine that would possibly be suitable for use in general practice. This is the EMIT-st drug detection system. It is marketed by Syva UK as a portable kit and costs $£ 3500$ exclusive of test phials and controls for the individual tests. Its main use is in drug dependency units doing large numbers of tests and it would not be cost effective for occasional use in general practice. It is simple to use but requires some initial training, and positive results should be confirmed by the laboratory if possible. It would not be sensible to install the system without discussing it first with the local laboratory.-LINDA BEELEY, consultant clinical pharmacologist, Birmingham. 